\title{
Tagging chromatin with retrotransposons: target specificity of the Saccharomyces Ty5 retrotransposon changes with the chromosomal localization of Sir3p and Sir4p
}

\author{
Yunxia Zhu, ${ }^{1}$ Sige Zou, ${ }^{1,2}$ David A. Wright, and Daniel F. Voytas ${ }^{3}$ \\ Department of Zoology and Genetics, Iowa State University, Ames, Iowa 50011 USA
}

\begin{abstract}
Retrotransposon and retroviral insertions are not randomly distributed on chromosomes, suggesting that retroelements actively select integration sites. This is the case for the yeast Ty5 retrotransposons, which preferentially integrate into domains of silent chromatin at the $H M$ loci and telomeres. Here we demonstrate that loss of Sir3p or Sir4p-components of silent chromatin—causes a greater than ninefold decrease in Ty5 targeting to the $H M$ loci and largely randomizes chromosomal integration patterns. Strains with a deletion of SIR4 also display an 10-fold increase in cDNA recombination, which is due both to the expression a- and $\alpha$-mating-type information and the loss of Sir4p. It is known that in old yeast cells or in strains carrying the sir4-42 allele, the Sir complex relocalizes to the rDNA. About $26 \%$ of Ty5 insertions occur within the rDNA in sir4-42 strains compared with $3 \%$ in wild type. Ty5, therefore, is sensitive to changes in chromatin, indicating that retrotransposons may be useful for dissecting chromatin dynamics that occur during developmental programs such as aging.
\end{abstract}

[Key Words: Retrotransposon; integration; silent chromatin; recombination; target specificity]

Received May 24, 1999; revised version accepted August 30, 1999.

Reverse transcription as carried out by the retroviruses and retrotransposons occurs within a nucleoprotein complex in the cell cytoplasm. The resulting cDNA is transported into the nucleus as part of an integration complex, a key component of which is the retroelementencoded integrase (Brown 1997). Integrase carries out the strand scission and joining reaction that inserts the cDNA into the host genome. The nonrandom chromosomal distribution of retrovirus and retrotransposon insertions suggests that the integration complex discriminates among potential integration sites (Sandmeyer et al. 1990; Craigie 1992). Integration specificity is particularly pronounced for the retrotransposons, which are obligate genomic parasites, and targeting may allow retrotransposons to persist by avoiding the disruption of genes or other sequences critical for host survival (Boeke and Devine 1998).

To explain retroelement integration site selection, one widely held model suggests that the retroelement inte-

\footnotetext{
${ }^{1}$ These two contributed equally to this work.

${ }^{2}$ Present address: Howard Hughes Medical Institute, University of California at San Francisco, San Francisco, California 94143.

${ }^{3}$ Corresponding author.

E-MAIL voytas@iastate.edu; FAX (515) 294-6755.
}

gration complex interacts with DNA-bound proteins or components of chromatin (Bushman 1995). This serves to tether the integration machinery to the target site, resulting in the observed target site biases. The most compelling support for this model comes from the study of the Saccharomyces cerevisiae retrotransposons (five families, designated Ty1-Ty5) (Boeke and Sandmeyer 1991). In the S. cerevisiae genome, $>90 \%$ of native Ty1Ty4 insertions are found in the upstream regions of genes transcribed by RNA polymerase III (Pol III), such as tRNA genes (Kim et al. 1998). For Tyl and Ty3, this genomic organization is due to targeted integration, which requires the assembly of the RNA Pol III transcription complex (Chalker and Sandmeyer 1992; Devine and Boeke 1996). Mutations that abolish the binding of Pol III transcription factors abolish targeted integration. For Ty3, the transcription factors TFIIIB and TFIIIC are sufficient for targeting in vitro when they are loaded onto a tRNA gene template (Kirchner et al. 1995). Thus the Ty1 and Ty3 integration complexes interact with a component of the RNA Pol III transcriptional apparatus or recognize a chromatin state associated with RNA Pol III transcription.

The Ty5 elements display a markedly different target bias $\longrightarrow 90 \%$ of Ty5 integration events occur near the 
telomeres or silent mating loci, $H M L$ and $H M R$ (Zou et al. 1996a,b). The telomeres and HM loci are bound in silent chromatin, which is analogous to heterochromatin of higher eukaryotes (for recent reviews, see Loo and Rine 1995; Lustig 1998). Silent chromatin has a number of cellular functions-it represses transcription of the $H M$ loci, is involved in telomere maintenance, and plays a role in senescence. Components of silent chromatin assemble at specific cis-acting sequences, which for the $H M$ loci are the flanking transcriptional silencers designated $\mathrm{E}$ and I. These silencers bind the transcriptional regulators Raplp and Abflp as well as the origin recognition complex (ORC). These same proteins also bind to sequences near the telomeres, either to the telomeric $\mathrm{TG}_{1-3}$ repeats (Raplp) or to sites within the subtelomeric $\mathrm{X}$ repeats (Abflp and ORC). These DNA-binding proteins nucleate the assembly of the many other components of silent chromatin, including the well-studied silent information regulators, Sirlp-Sir4p. Sirlp acts primarily to establish silencing at the HM loci, whereas Sir2p, Sir3p, and Sir4p are considered structural components of silent chromatin. They nucleate at the silencers and spread out to create a hypoacetylated chromatin domain.

Studies of the requirements for Ty5 target specificity support the general model that integration complexes recognize chromatin or other DNA-bound proteins such as transcription factors. Ty5 typically integrates within an $\sim 3$-kb window encompassing the $H M$ transcriptional silencers or the subtelomeric X repeat (Zou et al. 1996a, b). Silent chromatin determines Ty5 target preference, because mutations in $H M R-E$ that fail to assemble silent chromatin also fail to direct Ty5 integration (Zou and Voytas 1997). Mutations in individual protein-binding sites within the silencer, however, have only modest effects on targeting, suggesting that the integration complex may not interact directly with DNA-bound proteins (e.g., Rap1, Abf1, ORC), but rather with the factors they recruit to establish the silent state. Studies of Ty5-encoded factors required for targeting suggest that integrase itself may physically interact with a component of silent chromatin to mediate target choice. A single amino acid change near the carboxyl terminus of Ty5 integrase was found to randomize Ty5 integration patterns (Gai and Voytas 1998).

Chromatin states are not static. Reorganization of chromatin, which occurs during the onset of particular developmental programs, may alter retroelement targeting patterns. In $S$. cerevisiae, the rDNA is another domain of silent chromatin, and rDNA silencing depends on the silent information regulator Sir2p (Bryk et al. 1997; Smith and Boeke 1997). Sir3p and Sir4p dramatically change their distribution between the telomeres/ $H M$ loci and the rDNA as yeast cells age. The first evidence for this was provided by the isolation of a carboxyterminal truncated allele of SIR4 (sir4-42), which prolongs the life span of yeast cells (Kennedy et al. 1995). It was proposed that sir4-42 mediates its effect by preventing recruitment of the Sir complex to the telomeres and $H M$ loci, thereby increasing their concentration at hypothetical $A G E$ loci-regulators of life span. Indirect immunofluorescence studies showed that in both sir4-42 and old wild-type cells, Sir3p and Sir4p relocalize from the telomeres to the rDNA (nucleolus), suggesting that the rDNA is the AGE locus (Kennedy et al. 1997). More recently, rDNA breakdown has been shown to mark the onset of senescence in yeast, and yeast life span is measured by a clock calibrated to the accumulation of rDNA circles that result from recombination between rDNA repeats (Sinclair et al. 1998). The relocalization of the Sir complex to the rDNA during aging or in sir4-42 strains likely reorganizes chromatin and mitigates the onset of rDNA recombination and senescence.

In this work, we further explore the model that retroelement target specificity results from the recognition of specific chromatin components during integration. In particular, we analyze Ty5 integration patterns in strains with deletions of individual SIR genes, and we demonstrate that in strains lacking Sir3p or Sir4p, Ty5 target specificity is largely abolished. In addition, we found that in sir4-42 strains, wherein the Sir complex relocalizes from the telomeres to the nucleolus, Ty5 integrates preferentially into the rDNA. This indicates that retroelements like Ty5 are highly sensitive to changes in chromatin structure and can be used to map chromatin domains or to tag chromatin states that change during specific developmental programs.

\section{Results}

\section{Assays for Ty5 cDNA integration and recombination}

Because of the Ty5's preference to integrate into domains of silent chromatin, the Sir proteins were viewed as likely candidates for being recognized by the Ty 5 integration complex. We used strains with deletions in individual SIR genes to assess their role in integration and recombination. In our transposition assay, Ty5 transcription is controlled by a galactose-inducible promoter, and the donor Ty5 element carries a marker gene (his3AI) that is rendered nonfunctional because of the presence of an artificial intron (Zou et al. 1996a; Fig. 1). When cells with the donor element are grown on galactose, transcription is induced, and the artificial intron is spliced from the Ty5 mRNA. Reverse transcription of the spliced message reconstitutes a functional HIS3 gene. A $\mathrm{His}^{+}$phenotype can result either when Ty5 cDNA integrates into the genome, recombines with the his $3 A I$ marker on the donor plasmid, or recombines with a chromosomal substrate (Ke and Voytas 1997, 1999). Plasmid and chromosomal events are distinguished by growing cells on synthetic complete medium without histidine and with 5-fluoroorotic acid (SC-H + 5-FOA). 5-FOA selects against the plasmid-borne URA3 gene, and, therefore, cells in which the HIS3 marker has recombined with the plasmid will not grow on SC-H + 5-FOA medium. Cells that survive this selection (i.e., $\mathrm{His}^{+} / 5-\mathrm{FOA}^{\mathrm{r}}$ cells) include Ty5 chromosomal integration and recombination events-the latter are typically gene conversions of the his3-11,15 allele (see data below). These can 


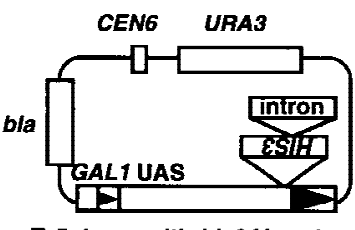

Ty5 donor with his3Al marker

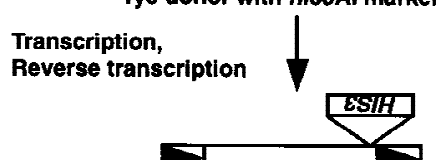

Ty5 CDNA

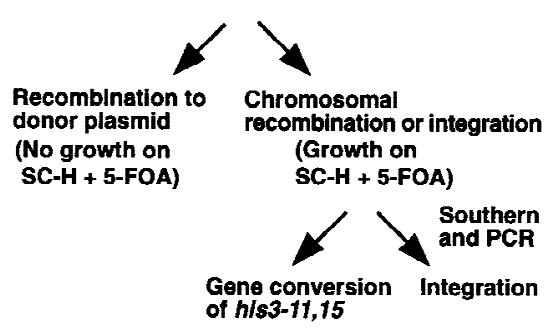

Figure 1. An assay to monitor Ty5 integration and recombination. The Ty5 donor element carries a his $3 A I$ marker gene that is interrupted by an artificial intron. The intron is in the incorrect orientation to be spliced from the HIS 3 transcript; however, it can be spliced from the Ty5 mRNA, and a functional HIS3 gene is generated only when the spliced transcript is reverse transcribed. Ty5 cDNA can either integrate into its target or recombine with homologous substrates. Because the yeast genome contains only a few degenerate Ty5 elements (Kim et al. 1998), recombination primarily occurs with the plasmid-borne his3AI marker or the chromosomal his3-11,15 allele (Ke and Voytas 1999|. Plasmid recombination and chromosomal events (either recombination or integration) can be distinguished by growth on synthetic complete medium without histidine and with 5-FOA (SC-H + 5-FOA). 5-FOA selects against the plasmidborne URA3 gene (Boeke et al. 1987), and strains that are His ${ }^{+}$ because of plasmid recombination will not grow on SC-H + 5FOA medium. Chromosomal recombination and integration are then distinguished by Southern blot analysis or PCR screens (see Materials and Methods).

be distinguished by Southern blot or PCR analysis (see Materials and Methods for details).

\section{The effect of Sir proteins on Ty5 cDNA integration} and recombination

The frequencies of $\mathrm{His}^{+}$cell formation were higher in the SIR deletion strains than in the wild-type strain (Table
1). This was primarily due to an increase in cDNA recombination, because integration frequencies were modestly lower. The high-efficiency recombination phenotype was most pronounced for $\Delta$ sir4 strains, which exhibited a $>10$-fold increase in the frequency of $\mathrm{His}^{+}$cell formation, a very high percentage of plasmid recombination $(91 \%$ vs. $38 \%$ in wild type) and a very low percentage of chromosomal integration $(3.3 \%$ vs. $58.9 \%$ in wild type). Loss of the Sir proteins results in derepression of the $H M$ loci and the expression of both $\mathbf{a}$ - and $\alpha$-mating type information. To distinguish between contributions made directly by loss of Sir proteins as opposed to the consequential derepression of the silent mating-type loci, the HMR locus was deleted in each of the MATa $\Delta$ sir strains. In $\Delta \operatorname{sir} 1 \Delta h m r, \Delta s i r 2 \Delta h m r$, and $\Delta \operatorname{sir} 3 \Delta h m r$, the overall $\mathrm{His}^{+}$frequency and the frequency of plasmid recombination were comparable with wild-type and lower than the $\Delta$ sir strains, and the percentage of plasmid recombination was intermediary to the wild-type and the $\Delta$ sir strains (Fig. 2). This suggests that the derepression of the silent mating loci is the primary contributor to the high efficiency of recombination and that the loss of the Sir proteins, Sir2p, and Sir3p, only contribute to the increase of the percentage recombination. A control strain (MAT $\alpha$ HMR-E aeb) with a silencer mutation that expresses both $\mathbf{a}$ - and $\alpha$-mating-type information confirmed the contribution made by derepression of the silent mating type loci to the high recombination phenotype. For the $\Delta \operatorname{sir} 4 \Delta h m r$ strain, the frequency of $\mathrm{His}^{+}$cell formation was more than four fold greater than wild type, and the percent cDNA recombination was higher than the wild-type and other $\Delta$ sir $\Delta h m r$ strains $(71.2 \%$ vs. $28.0 \%-53.8 \%)$. In contrast to the other double mutants, the high efficiency and high percentage of recombination phenotype appears to be the result of a synergistic effect resulting from the derepression of the silent mating-type loci and the loss of Sir4p.

An example of Southern blot analysis used to distinguish chromosomal integration and gene conversion is shown in Figure 3. Filters containing DNA from 12 independent $\mathrm{His}^{+} / 5$-FOA ${ }^{\mathrm{r}}$ wild-type or $\Delta$ sir4 strains were hybridized with Ty5 or HIS3 probes. In the case of the wild-type strain, 11/12 have Ty5 sequences and two copies of HIS3 - the endogenous his3-11,15 allele and the HIS3 associated with Ty5. For $\Delta$ sir4, only 4/12 $\mathrm{His}^{+} / 5-$ FOA $^{\mathrm{r}}$ strains carry Ty5-HIS3. One of the $\Delta$ sir4 strains (see Fig. 3B,D) carries several copies of Ty5, which we often observe when Ty5 integration is blocked (Ke and

Table 1. Ty5 integration and recombination in wild-type and $\Delta$ sir strains

\begin{tabular}{lcccccc}
\hline Genotype & $\begin{array}{c}\text { Frequency of } \mathrm{His}^{+} \\
\text {cell formation } \\
\left(10^{-6}\right)\end{array}$ & $\begin{array}{c}\text { Percent plasmid } \\
\text { recombination }\end{array}$ & $\begin{array}{c}\text { Percent } \\
\text { chromosomal } \\
\text { recombination }\end{array}$ & $\begin{array}{c}\text { Percent } \\
\text { chromosomal } \\
\text { integration }\end{array}$ & $\begin{array}{c}\text { Integration } \\
\text { frequency } \\
\left(10^{-6}\right)\end{array}$ & $\begin{array}{c}\text { Fold reduction } \\
\text { in integration } \\
\text { frequency }\end{array}$ \\
\hline Wild type & $4.64 \pm 1.62$ & 38.0 & 3.1 & 58.9 & 2.73 & N.A. \\
$\Delta$ sir 1 & $5.78 \pm 0.40$ & 64.8 & 1.2 & 34.0 & 1.96 & 1.4 \\
$\Delta$ sir2 & $11.7 \pm 0.14$ & 87.2 & 2.1 & 10.7 & 1.25 & 1.45 \\
$\Delta$ sir3 & $7.56 \pm 1.25$ & 78.2 & 2.6 & 3.2 & 1.71 & 1.9 \\
$\Delta$ sir4 & $51.8 \pm 1.77$ & 91.0 & 5.7 & 3.3 & 1.6 \\
\hline
\end{tabular}

(N.A.) Not applicable. 


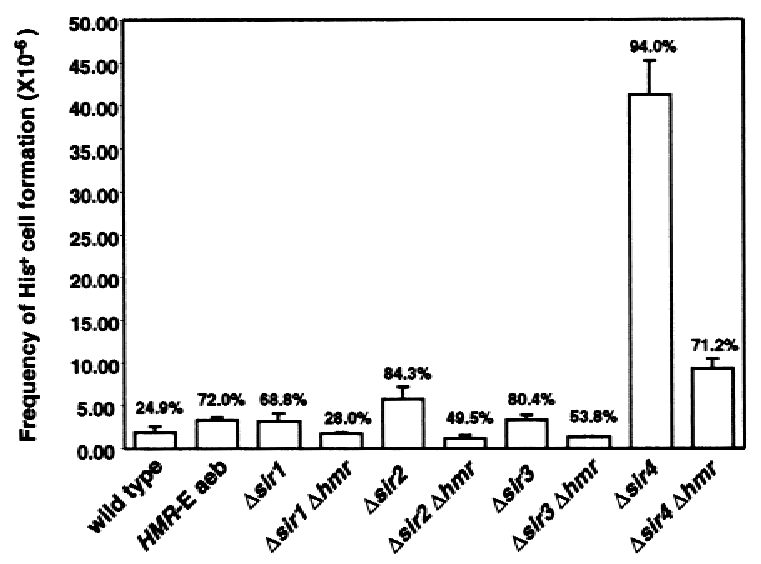

Figure 2. Ty5 cDNA plasmid recombination in $\Delta$ sir and $\Delta$ sir $\Delta h m r$ mutants. The frequency of $\mathrm{His}^{+}$cell formation and the percentage of plasmid recombination were measured as described in the Materials and Methods and the legend to Fig. 1. All strains are MAT $\alpha$. The value above each bar is the percentage of plasmid recombination.

Voytas 1999). For both the wild-type and $\Delta$ sir4 strains, the presence of Ty5 sequences was scored as integration and the lack of Ty5 sequences was scored as gene conversion of his3-11,15.

Because of the high rates of cDNA recombination, we felt that we may have underestimated the effects of SIR deletions on integration. For example, it is difficult to

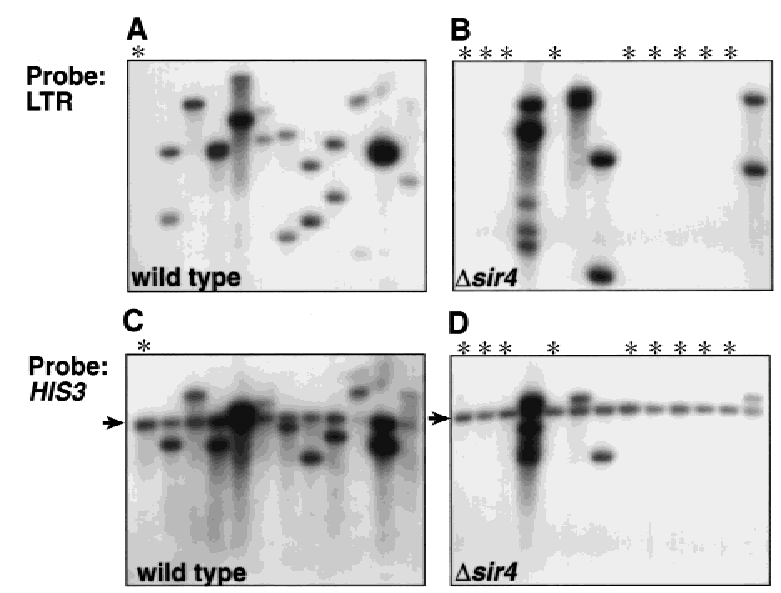

Figure 3. Gene conversion of his3-11,15 by Ty5 cDNA is enhanced in $\Delta$ sir4 strains. Ty5 transposition was induced in wildtype or $\Delta$ sir4 strains, and DNA was prepared from 12 independent $\mathrm{His}^{+} / 5$-FOA ${ }^{\mathrm{r}}$ strains. DNA was digested with $\mathrm{HpaI}$, which cuts $2.4 \mathrm{~kb}$ from the $5^{\prime}$ end of the 6.4-kb Ty5 element. Southern filters were prepared and hybridized with an LTR probe $(A, B)$. Filters were stripped and rehybridized with a HIS3 probe $(C, D)$. The presence of Ty5 in a given strain is indicated by hybridization to the LTR probe. In all cases, strains with Ty5 LTRs also had two restriction fragments that hybridized to HIS3 - one representing the HIS3 marker in Ty5 and the other the his3-11,15 allele (arrow). $~^{*}$ ) His $^{+}$strains lacking Ty5 sequences were considered to have arisen by gene conversion of the his3-11,15 allele by Ty 5 cDNA. distinguish integration events from recombination of Ty5 cDNA with the native Ty5 elements on the yeast chromosomes. Native elements are degenerate, and although we have never previously observed such recombination events in wild-type strains, their frequency could be increased if integration were affected by SIR deletions. To get a more accurate estimate of the effect of SIR deletions on Ty5 integration, we also measured integration in $\Delta$ sir2, $\Delta$ sir3, and $\Delta$ sir4 strains in which the RAD52 gene was deleted to eliminate homologous recombination (Petes et al. 1991; Table 2). We found that the deletion of RAD52 did not significantly affect integration frequency in wild-type strains. However, integration in $\Delta$ sir $\Delta$ rad52 double mutants was reduced relative to the individual $\Delta$ sir strains and the $\Delta$ rad52 single mutant, suggesting that recombination with the native Ty5 sequences may occur at appreciable levels in $\Delta$ sir backgrounds. Alternatively, there could be a synergistic transposition defect caused by loss of the SIR and $R A D 52$ gene products; this remains to be tested.

\section{Deletion of SIR3 or SIR4 impairs targeting of Ty5 to the HM loci}

To determine whether the Sir proteins are important for Ty5 target specificity, we monitored integration near each of the four HM silencers in either wild-type strains or strains with deletion in each of four SIR genes. For this study, we modified a PCR assay used previously to measure targeting of Ty5 to the HMR-E transcriptional silencer (Zou and Voytas 1997). Transposition was induced and genomic DNA was prepared in pools representing 10 independent $\mathrm{His}^{+} / 5$-FOA ${ }^{\mathrm{r}}$ strains. DNA pools were PCR-amplified four times; each reaction contained two primers specific for the Ty5 long terminal repeat (LTR) and two primers flanking a given silencer (Fig. 4). The position of the primers made it possible to detect integration events within $\sim 2$-kb windows flanking each silencer, which in total represent $\sim 0.06 \%$ of the genome. Because the $\mathrm{His}^{+} / 5-\mathrm{FOA}^{\mathrm{r}}$ strains include both chromosomal integration and chromosomal recombination events, the effective number of integration events was adjusted with the data from Table 1.

Targeting to the HM loci was differentially affected by the SIR mutations (Table 3). Deletion of SIR1 slightly reduced targeting, whereas deletion of SIR2 decreased

Table 2. Ty5 integration in homologous recombination-deficient yeast strains

\begin{tabular}{lcc}
\hline Genotype & $\begin{array}{c}\text { Integration } \\
\text { frequency } \\
\left(10^{-6}\right)\end{array}$ & $\begin{array}{c}\text { Fold reduction } \\
\text { in integration } \\
\text { frequency }\end{array}$ \\
\hline rad52 & $2.08 \pm 0.27$ & N.A. \\
$\Delta$ sir2 $\Delta$ rad52 & $0.30 \pm 0.08$ & 6.81 \\
$\Delta$ sir3 rad52 & $0.44 \pm 0.11$ & 4.68 \\
$\Delta$ sir4 $\Delta$ rad52 & $0.38 \pm 0.16$ & 5.42 \\
sir4-42 $\Delta$ rad52 & $0.62 \pm 0.08$ & 3.34 \\
\hline
\end{tabular}

(N.A.) Not available. 

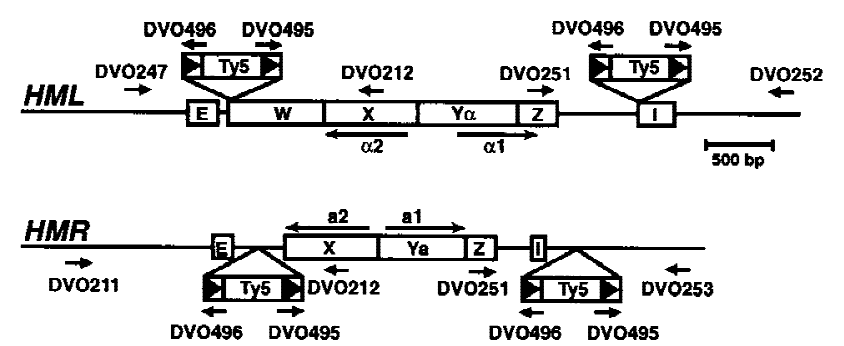

Figure 4. A PCR assay to identify Ty5 insertions near the $H M$ loci. At both the $H M L$ and $H M R$ loci, E and I represent the flanking transcriptional silencers. $\mathrm{W}, \mathrm{X}$, and $\mathrm{Z}$ are homologous regions shared between the $H M L, H M R$, or MAT. Y $\alpha$ and $\mathrm{Ya}$ are specific for $H M L$ and $H M R$, respectively. Transcripts $(\mathbf{a} 1, \mathbf{a} 2 \alpha 1$, $\alpha 2)$ at each locus are shown by the longer horizontal arrows. Primers used in the PCR amplifications are labeled with their DVO designator. DNA was prepared in pools, each consisting of 10 independent $\mathrm{His}^{+} / 5-\mathrm{FOA}^{\mathrm{r}}$ strains. The pooled DNA was amplified four times to detect integration events within an $\sim 2-\mathrm{kb}$ window near each of the four $H M$ silencers. Each reaction included two Ty5-specific primers (DVO496, DVO495) and two primers flanking a given silencer (e.g., DVO247 and DVO212 for $H M L-E)$. Because most strains did not carry a Ty5 insertion within the tested interval, amplification from the primers flanking the silencer generated a fragment of $\sim 2 \mathrm{~kb}$; this fragment served as an internal control for the PCR reactions. Fragments $<2 \mathrm{~kb}$ indicated the presence of a Ty5 insertion, which was then confirmed by amplifying the pooled DNA through additional rounds of PCR with individual Ty5 and silencer primers.

targeting 3.7-fold. Targeting was reduced 9.4-fold in $\Delta$ sir3, and no targeted events were detected in the $\Delta$ sir4 strain. Despite the targeting decrease in $\Delta$ sir2 and $\Delta$ sir3, the frequencies of $H M$ insertions were at least 10 times greater than predicted for random integration in the genome. This suggests that although targeting is impaired, the Ty5 integration complex can still preferentially recognize these loci.

\section{Chromosomal integration patterns in $\Delta$ sir strains}

To determine the effect of SIR deletions on chromosomal integration patterns, independent transposition events in $\Delta$ sir2, $\Delta$ sir3, and $\Delta$ sir4 strains were characterized. Sequences flanking Ty5 integration sites were amplified by inverse PCR, sequenced, and mapped onto the complete $S$. cerevisiae genome sequence. We typically use the ORC-binding site-the autonomously replicating consensus sequence (ACS) within either the telomeric $\mathrm{X}$ repeat or the $H M$ silencers-as a guidepost to orient integration events. Insertions were considered targeted if they occurred within $1.5 \mathrm{~kb}$ of such an ACS. By this definition, $\sim 90 \%$ of Ty 5 transposition events are targeted in wild-type strains (Zou et al. 1996a,b).

We observed that the absence of Sir proteins altered chromosomal integration patterns (Table 4). Among ten insertions characterized in the $\Delta$ sir2 strain, four met our definition of targeted events, one was within a telomeric $\mathrm{Y}^{\prime}$ element duplicated at the ends of chromosomes IX and $\mathrm{X}$, one was located in the rDNA array, and the other four were randomly distributed in the genome. Of eleven insertions in the $\Delta$ sir3 strain, one was targeted, three were clustered within the chromosome IX/X Y' element, and the remainder were distributed throughout the genome. Among nine insertions in the $\Delta$ sir4 strain, one was targeted, two were within or near Tyl elements, and the rest were randomly dispersed. As with the $H M$ targeting assay, deletion of SIR3 or SIR4 had the most significant effect on Ty5 target specificity.

\section{Ty5 integration occurs preferentially within Ty elements and the rDNA in sir4-42 strains}

As cells age, Sir3p and Sir4p move from the telomeres and the silent mating loci to the rDNA (Kennedy et al. 1997). This relocalization is also observed in strains carrying the sir4-42 allele, which produces a carboxy-terminal truncated SIR4 protein. We monitored Ty5 integration efficiency and targeting in a sir4-42 strain. Compared with the $\Delta$ sir4 strain, frequencies of $\mathrm{His}^{+}$cell formation and cDNA recombination were largely indistinguishable (data not shown). Integration efficiency in a sir4-42 $\Delta$ rad52 strain was slightly higher than in a $\Delta$ sir4 $\Delta$ rad52 strain (Table 2). A high frequency of cDNA recombination was observed on characterization of chromosomal insertions. Of nineteen independent chromosomal events analyzed in sir4-42, four were tandem elements (data not shown), which arose through recombination with the native Ty5-1 element near the left telomere of chromosome III (Voytas and Boeke 1992). Of the fifteen remaining chromosomal events, one integrated within the telomeric Ty5-1 element (Table 5). Interestingly, four were within pre-existing Tyl or Ty3 elements, and two were within 600 bases of such elements. Retrotransposon sequences as a whole constitute $3.1 \%$ of the genome (Kim et al. 1998), and the observation that $7 / 15$ insertions were associated with Ty elements suggests that Ty5 may be preferentially targeted to retrotransposons in sir4-42 strains.

Three of the fifteen insertions in the sir4-42 strain occurred within the rDNA array, which accounts for $\sim 10 \%$ of the $S$. cerevisiae genome (Cherry et al. 1997). To better characterize this apparent change in target specificity, we developed a PCR assay to quantitate and map integration events within the rDNA repeats (Fig. 5A). Ty5 insertions in the rDNA were amplified by PCR using rDNA- and Ty5 LTR-specific primers. Primers that amplify an internal portion of Ty5 served as a control for the PCR reaction and for the presence of Ty5 in the genome. Because Ty5-HIS3 cDNA can recombine with the endogenous his3-11,15 allele at a high frequency, we used $\Delta$ rad52 strains for this assay. We observed a remarkable increase in targeting to the rDNA in the sir4-42 strain $(26 \%)$ compared with wild type $(3 \%)$ (Table 6$)$. A modest (aproximately twofold) increase was also observed in the $\Delta$ sir2 and $\Delta$ sir4 strains.

Because the position of the primers within the rDNA is fixed, it was possible to map the approximate location of the insertions on the basis of the size of the amplification products (Fig. 5B). Two clusters of insertions were 
Table 3. The targeting efficiency of Ty5 to HM loci in wild-type and $\Delta$ sir strains

\begin{tabular}{lccccc}
\hline Genotype & $\begin{array}{c}\text { Chromosomal events } \\
\text { characterized }\end{array}$ & $\begin{array}{c}\text { Effective } \\
\text { integration events }\end{array}$ & $\begin{array}{c}\text { Insertions near } \\
H M \text { silencers }\end{array}$ & $\begin{array}{c}\text { Percent } \\
\text { targeting }\end{array}$ & $\begin{array}{c}\text { Fold reduction } \\
\text { in } H M \text { targeting }\end{array}$ \\
\hline Wild-type & 200 & 190 & 12 & 6.32 & N.A. \\
$\Delta$ sir 1 & 200 & 193 & 5 & 2.59 & 2.44 \\
$\Delta$ sir 2 & 210 & 175 & 3 & 1.71 & 3.70 \\
$\Delta$ sir 3 & 340 & 300 & 2 & 0.67 & 9.43 \\
$\Delta$ sir 4 & 230 & 84 & 0 & N.A. & N.A. \\
\hline
\end{tabular}

(N.A.) Not applicable.

${ }^{a}$ Effective integration events are calculated as the product of the chromosomal events characterized and the percent chromosomal integration (from Table 1) divided by the sum of the percent chromosomal integration and the percent chromosomal recombination (from Table 1).

identified; one flanks the $5 \mathrm{~S}$ gene and the other is near the junction of the $5.8 \mathrm{~S}$ and $25 \mathrm{~S}$ genes. Of the three rDNA insertions in sir4-42 that were identified by direct cloning (Table 5), two were located near the 5S gene and one was within the $25 \mathrm{~S}$ hotspot. Similarly, of the three wild-type rDNA insertions (Table 6), two were near the
$5 S$ and $25 S$ hotspots, and one was within the 18 S gene. In addition, there was no apparent preference to integrate on either strand of the rDNA. We conclude, therefore, that in sir4-42, not only is Ty5 target specificity changed, but the pattern of integration events within the rDNA locus is distinctly nonrandom.

Table 4. Chromosomal distribution of Ty5 insertions in $\Delta$ sir strains

\begin{tabular}{|c|c|c|c|c|}
\hline Strain & Chr. no. & Coordinate & Location $^{a}$ & Nearby chromosomal features \\
\hline \multicolumn{5}{|l|}{$\Delta \operatorname{sir} 2$} \\
\hline $\mathrm{T} 3$ & I & $\sim 600$ & $\mathrm{~T}$ & within YAL069W, $\sim 153$ bases from $\mathrm{X}$ repeat ACS \\
\hline $\mathrm{T} 4$ & VII & 287 & $\mathrm{~T}$ & 446 bases from ACS in X repeat \\
\hline $\mathrm{T} 17$ & IX or $\mathrm{X}$ & $\sim 8424$ & $\mathrm{~T}$ & $\sim 695$ bases from ACS in X repeat \\
\hline $\mathrm{T} 10$ & III & 293099 & $\mathrm{~T}$ & within $H M R, 506$ bases from ACS in $H M R$-I \\
\hline $\mathrm{T} 8$ & XIV & $\sim 1000$ & NT & within $\mathrm{Y}^{\prime}, 6165$ bases from core $\mathrm{X}$ repeat \\
\hline $\mathrm{T} 28$ & XII & 455677 & $\mathrm{R}$ & between genes for $5.8 \mathrm{~S}$ and $18 \mathrm{~S}$ rRNA \\
\hline $\mathrm{T} 4$ & VI & 1511923 & $\mathrm{D}$ & between PAD1 and YDR539W \\
\hline $\mathrm{T} 18$ & XI & 67821 & $\mathrm{D}$ & between MNN4 and YKT9 \\
\hline $\mathrm{T} 12$ & XIV & 91046 & $\mathrm{D}$ & within YNL288W \\
\hline $\mathrm{T} 20$ & $\mathrm{XV}$ & 891622 & $\mathrm{D}$ & between YOR306C and SLY41 \\
\hline \multicolumn{5}{|l|}{$\Delta \operatorname{sir} 3$} \\
\hline H29 & III & 1568 & $\mathrm{~T}$ & within Ty5-1 (YCLWTy5-1), 515 bases from ACS in X repeat \\
\hline H11 & IX or $\mathrm{X}$ & 87 & NT & within $\mathrm{Y}^{\prime}, 7632$ bases from ACS in $\mathrm{X}$ repeat \\
\hline H36 & IX or $\mathrm{X}$ & $\sim 97$ & NT & within $\mathrm{Y}^{\prime}, \sim 7622$ bases from ACS in $\mathrm{X}$ repeat \\
\hline $\mathrm{H} 25$ & IX or $\mathrm{X}$ & 395 & NT & within $\mathrm{Y}^{\prime}, 7324$ bases from ACS in X repeat \\
\hline $\mathrm{H} 24$ & I & 124455 & $\mathrm{D}$ & between FUN31 and TPD3 \\
\hline H31 & IV & 131105 & $\mathrm{D}$ & within YDL183C \\
\hline $\mathrm{H} 1$ & IV & 1186012 & $\mathrm{D}$ & between TRP4 and YDR355C \\
\hline H12 & $\mathrm{V}$ & 260751 & $\mathrm{D}$ & between YER053C and GIP2 \\
\hline H6 & $\mathrm{XV}$ & 721754 & $\mathrm{D}$ & between PET56 and HIS3 \\
\hline H5 & XVI & 105640 & $\mathrm{D}$ & between TFP3 and YPL233W \\
\hline $\mathrm{H} 4$ & XVI & 396718 & $\mathrm{D}$ & within SEN54 \\
\hline \multicolumn{5}{|l|}{$\Delta \operatorname{sir} 4$} \\
\hline F4 & XII & 11487 & $\mathrm{~T}$ & between YLL066C and YLL065W, 550 bases from ACS in X repeat \\
\hline F47 & $\mathrm{X}$ & 483062 & Ty & within Ty1 element YJRWTy1-2 \\
\hline F19 & XII & 796771 & NTy & within YLR333C, 127 bases from Ty1 insertion \\
\hline F10 & IV & 309450 & $\mathrm{D}$ & between $R P L 13 A$ and $R P L A 1$ \\
\hline F6 & VII & $\sim 330801$ & $\mathrm{D}$ & between VPS45 and PAN2 \\
\hline F36 & $\mathrm{XI}$ & 557166 & $\mathrm{D}$ & between YKR060W and KTR2 \\
\hline F3 & XII & 830607 & $\mathrm{D}$ & between YLR351C and YLR352W \\
\hline F37 & XIV & 317917 & $\mathrm{D}$ & between PSD1 and YNL168C \\
\hline F9 & $\mathrm{XV}$ & 825909 & $\mathrm{D}$ & within YOR268C \\
\hline
\end{tabular}

${ }^{a}(\mathrm{~T})$ Targeted insertions at the telomeres or HM loci; $(\mathrm{NT})$ telomeric insertions that do not meet our definition for targeting; (R) insertions within the rDNA; (Ty) insertions within Ty elements; (NTy) insertions within 750 bases of a Ty element; (D) dispersed insertions with no apparent target specificity. 
Table 5. Chromosomal distribution of Ty5 insertions in sir4-42

\begin{tabular}{|c|c|c|c|c|}
\hline Strain & Chr. no. & Coordinate & Location $^{\mathrm{a}}$ & Nearby chromosomal feature \\
\hline A19 & I & 165824 & Ty & within Ty1 LTR (YARCdelta5) \\
\hline A68 & $\mathrm{V}$ & 496010 & Ty & within Ty1(YERCTy1-2) \\
\hline A129 & XIII & 199915 & Ty & within Ty1 (YMLWTy1-2) \\
\hline A126 & XVI & 56341 & Ty & within Ty3 LTR (YPLWsigma1) \\
\hline A91 & $\mathrm{V}$ & 311723 & NTy & $\begin{array}{l}\text { between PTP3 and tA(UGC)E, } 547 \text { bases from } \\
\text { Ty1 LTR (YERWdelta11) }\end{array}$ \\
\hline A17 & VIII & 117119 & NTy & 65 bases from Ty1 LTR (YHRCdelta4) \\
\hline A99 & XII & 454867 & $\mathrm{R}$ & within gene for $25 \mathrm{~S}$ rRNA \\
\hline A103 & XII & 458723 & $\mathrm{R}$ & between genes for $18 \mathrm{~S}$ and $5 \mathrm{~S}$ rRNA \\
\hline $\mathrm{A} 20$ & XII & 460656 & $\mathrm{R}$ & near gene for $5 S$ rRNA \\
\hline A13 & III & 2685 & NT & $\begin{array}{l}\text { within Ty5 element (YCLWTy5-1), } 1632 \text { bases } \\
\text { from ACS in X repeat }\end{array}$ \\
\hline A89 & II & 161776 & $\mathrm{D}$ & within SHE1 \\
\hline A72 & II & 629008 & $\mathrm{D}$ & between $C D C 47$ and YBR203W \\
\hline A69 & VIII & 506793 & $\mathrm{D}$ & within YHR204W \\
\hline A62 & IX & 138988 & $\mathrm{D}$ & between RPI1 and RHO3 \\
\hline A8 & XIV & 733878 & $\mathrm{D}$ & within $\mathrm{BIO} 4$ \\
\hline
\end{tabular}

${ }^{a}(\mathrm{Ty})$ Insertions within Ty elements; (NTy) insertions within 750 bases of a Ty element; (R) insertions within the rDNA; (NT) telomeric insertions that do not meet our definition for targeted events; (D) dispersed insertions with no apparent target specificity.

\section{Discussion}

Sir3p and Sir4p are important for Ty5 target specificity

A general model to explain target specificity of the retroviruses and LTR retrotransposons invokes a physical interaction between the retroelement integration complex and chromosomal proteins (Bushman 1995). This tethers the integration complex to specific chromosomal sites, leading to the observed target site biases. This model is well supported by studies of the yeast Ty 5 retrotransposons. We have identified previously a domain near the carboxyl terminus of Ty5 integrase, which when mutated, abolishes the preference of this element to integrate into silent chromatin (Gai and Voytas 1998). This suggests that integrase is the chromatin sensor. We have also shown that silent chromatin is required for Ty5 target specificity. Mutations in the HMR-E silencer that disrupt the assembly of silent chromatin (as measured by transcriptional silencing) also abolish targeting (Zou and Voytas 1997). HMR-E binds three proteins or protein complexes-Abflp, Raplp, and ORC-which in turn help to recruit the Sir proteins (Loo and Rine 1995; Lustig 1998). Because the Sir complex is found at both the telomeres and HM loci and is required for silencing, we felt that the Sir proteins were likely candidates for being recognized by the Ty 5 integration complex.

In this study, we tested Ty5 target specificity in strains with deletions in each of the four SIR genes. Deletion of either SIR3 or SIR4 resulted in a greater than ninefold decrease in integration at the HM loci. When integration patterns were characterized at the chromosomal level, only $1 / 10 \Delta$ sir3 insertions and $1 / 9 \Delta$ sir4 insertions were targeted to silent chromatin /defined as within $1.5 \mathrm{~kb}$ from the ACS within an $H M$ silencer or the telomeric $\mathrm{X}$ repeat). This contrasts with $\sim 90 \%$ targeting observed in wild-type strains (Zou et al. 1996a,b). In $\Delta$ sir1, targeting to the HM loci was modestly affected (down 2.44-fold).
Sirlp acts primarily at the $H M$ loci to help establish silencing (Pillus and Rine 1989; Aparicio et al. 1991), and because Ty5 integrates efficiently at both telomeres and the $H M$ silencers, this result was not unexpected. $\Delta$ sir2 strains had an intermediary effect; $H M$ targeting was decreased 3.77-fold and 4/10 chromosomal insertions were targeted. Sir2p is required for transcriptional silencing at telomeres, HM loci, and rDNA. The observation that targeting is partially functional in $\Delta$ sir2 strains indicates that transcriptional silencing and Ty5 target specificity are genetically separable.

Although Sir3p and Sir4p are important for targeting, targeted transposition events were still recovered in $\Delta$ sir3 and $\Delta$ sir4 strains at frequencies approximating $10 \%$; the target window $(1.5 \mathrm{~kb}$ from an ACS within the $H M$ silencers or $\mathrm{X}$ repeat) accounts for $<1 \%$ of the genome (Cherry et al. 1997). This indicates that whereas targeting is greatly diminished in $\Delta$ sir3 and $\Delta$ sir4 strains, insertions into silent chromatin still occur at frequencies significantly greater than random. This suggests that Sir3p and Sir4p are not the only factors important for Ty5 target specificity. The Ty5 integration complex may interact with multiple factors, or Sir3p and Sir4p may stabilize or recruit additional factors required for optimal targeting. With our recently identified Ty5 targeting domain, we are currently using a variety of genetic and biochemical means to identify candidate interactors. It is important to note, however, that at this time we cannot exclude alternative models to explain target specificity. For example, one model suggests that there may be a silent compartment within the nucleus (Boeke and Devine 1998). In such a scenario, the Ty5-encoded targeting domain would serve as a localization signal to direct the integration complex to this subnuclear compartment. Once localized, integration would take place into the available DNA, giving rise to the observed target bias. 
A

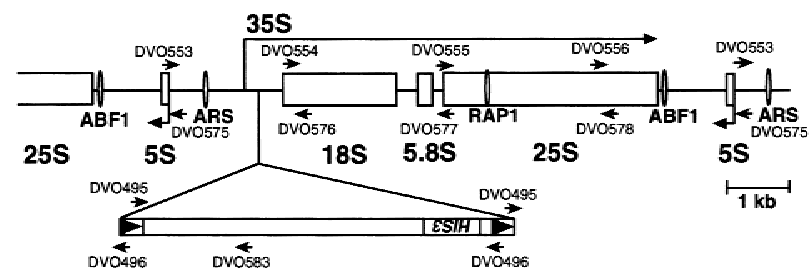

B

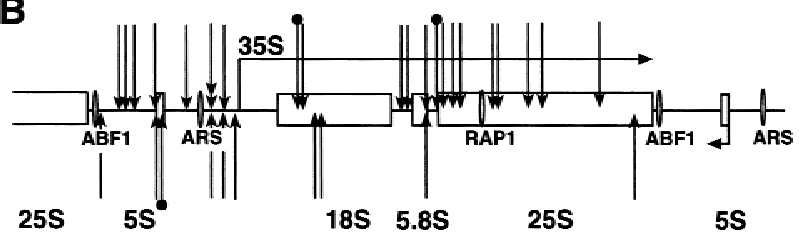

Figure 5. (A) A PCR assay to identify Ty5 insertions within the rDNA. Genomic DNA was extracted from individual $\mathrm{His}^{+} / 5-$ FOA $^{\mathrm{r}}$ strains, each representing an independent Ty5 integration event. Insertions within the rDNA were detected by PCR with three Ty5-specific primers and four rDNA primers, the latter of which were complementary to the same DNA strand. Two of the Ty 5 primers amplify an internal portion of the element; this served as a control for the PCR reaction and demonstrated that Ty5 was present in the genome. An amplification product other than the Ty5 control fragment indicated an insertion within the rDNA. Additional PCR reactions with individual rDNA primers made it possible to pinpoint the integration site. (Open boxes) 18S, 5.8S, 25S, and 5S rRNA genes. The direction of transcription is indicated. (ABF1, RAP1) Characterized binding sites for these proteins (Buchman et al. 1988, Kang et al. 1995); (ARS) an origin of DNA replication (Miller and Kowalski 1993). Oligonucleotides used in the PCR assay are labeled by their DVO designator. (B) The location of Ty5 insertions within the rDNA. (Vertical arrows) Sites of insertion; (arrows with circular tails) the three rDNA insertions identified from the 100 wildtype strains in Table 6. All others represent the 29 insertions identified in sir4-42 (Table 6). (Arrows pointing down) Insertions in the same $5^{\prime}$ to $3^{\prime}$ orientation as the $35 \mathrm{~S} \mathrm{rDNA}$; (arrows pointing up/ insertions in the opposite orientation.

\section{The Sir complex and Ty5 cDNA recombination}

In addition to their effect on Ty5 integration specificity, loss of Sir proteins influenced Ty5 cDNA recombination. We measured Ty5 integration or recombination by the His ${ }^{+}$phenotype that results when Ty5 cDNA joins a plasmid or chromosomal substrate. Deletions of each of the SIR genes increased the overall frequency of $\mathrm{His}^{+}$cell formation, and this increase was due to an increase in cDNA recombination. For $\Delta$ sir $1, \Delta$ sir2, and $\Delta$ sir3 strains, plasmid recombination increased from 1.7- to 2.3-fold. Loss of Sir proteins results in the expression of the silent mating loci, and we previously observed comparable increases in cDNA recombination in strains with silencer mutations that express both a- and $\alpha$-mating-type information (Zou and Voytas 1997). In this study we assayed recombination in $\Delta$ sir strains that expressed only $\alpha$-mating-type information, and we found that most of the increase in cDNA recombination in the $\Delta$ sir single mutants was due to the change in the expression of mating- type information. Integration also decreased slightly in $\Delta$ sir1, $\Delta$ sir2, and $\Delta$ sir3 strains. Shifts in the balance of integration and recombination have been observed for Ty5 and Ty1 as a consequence of mutations in integrase (Sharon et al. 1994; Ke and Voytas 1999). In the $\Delta$ sir strains, it is possible that cDNA is produced more efficiently or that more cDNA is diverted to the recombination pathway.

A particularly pronounced effect on cDNA recombination was observed for the $\Delta$ sir 4 strain. It showed a $>10$-fold increase in the frequency of $\mathrm{His}^{+}$cell formation, of which $91 \%$ of the events were due to plasmid recombination, $5.7 \%$ to chromosomal recombination, and only $3.3 \%$ were integration events. This contrasts with wild type, in which $38 \%$ of the $\mathrm{His}^{+}$cells were due to plasmid recombination, $3.1 \%$ to chromosomal recombination and $58.9 \%$ to integration. The high frequency of $\mathrm{His}^{+}$cell formation in $\Delta$ sir4 appears to be the result of contributions made by both the expression of the mating-type loci and the loss of Sir4p. Although the mechanism by which this occurs cannot yet be ascertained, possibilities include a general increase in homologous recombination, inhibition of cDNA degradation, an increase in cDNA synthesis, or an alteration in the structure of the integration complex that makes more cDNA available for recombination. Recently, the Sir complex has been found to play a role-either directly or indirectly-in nonhomologous end joining (NHEJ) (Astrom et al. 1999; Martin et al. 1999; Mills et al. 1999). The mammalian NHEJ pathway requires Ku70 and Ku80, DNA-binding components of the DNA-dependent protein kinase, which are required to complete retroviral integration (Daniel et al. 1999). Sir4p physically interacts with Hdf1p - the yeast Ku70 homolog (Tsukamoto et al. 1998), and this may explain the decrease in integration efficiency observed in $\Delta$ sir backgrounds. The precise mechanism by which Sir4p and the other Sir proteins impact Ty5 homologous cDNA recombination and integration is the subject of ongoing experimentation.

\section{rDNA targeting in sir4-42}

If the model for retroelement target specificity is correct, namely that integration complexes interact with chromatin, then changes in chromatin states that occur during the onset of developmental programs would be predicted to impact target specificity. The Sir complex undergoes a dramatic reorganization at the onset of senescence. Immunofluorescence studies have demon-

Table 6. Targeting efficiency of Ty5 to rDNA

\begin{tabular}{|c|c|c|c|}
\hline Genotype & $\begin{array}{c}\text { Chromosomal } \\
\text { events } \\
\text { characterized }\end{array}$ & $\begin{array}{l}\text { Number } \\
\text { of rDNA } \\
\text { insertions }\end{array}$ & $\begin{array}{c}\text { Percent } \\
\text { rDNA } \\
\text { insertions }\end{array}$ \\
\hline$\Delta$ rad52 & 100 & 3 & $3.0 \%$ \\
\hline$\Delta$ sir2 $\Delta$ rad52 & 102 & 6 & $5.9 \%$ \\
\hline$\Delta$ sir4 $\Delta$ rad52 & 94 & 6 & $6.4 \%$ \\
\hline sir4-42 $\Delta \mathrm{rad} 52$ & 113 & 29 & $26 \%$ \\
\hline
\end{tabular}


strated that Sir3p and Sir4p move from the telomeres to the rDNA (nucleolus) as yeast cells age (Kennedy et al. 1997). Like in old cells, Sir3p and Sir4p are constitutively located within the nucleolus in strains carrying the sir442 allele.

We have shown that Ty5 target specificity is dramatically altered in sir4-42 strains. Only 3\% of Ty5 integration events occur within the rDNA in wild-type strains, and this increases to $26 \%$ in sir4-42 strains. Not only does Ty 5 follow the movement of the Sir complex, but also the pattern of integration events within the rDNA suggests how this chromatin is organized. Ty5 insertions predominantly occur at two locations within the rDNA-one near the 5S rRNA gene and the other near the junction of the $5.8 \mathrm{~S}$ and $25 \mathrm{~S}$ genes. These regions are roughly coincident with binding sites for three proteins or protein complexes that assemble at the subtelomeric $\mathrm{X}$ repeats and the $H M$ silencers (Fig. 5). ORC and Abf1p have been shown to bind on either side of the $5 S$ gene (Miller and Kowalski 1993; Kang et al. 1995), and the 25S integration hotspot is largely coincident with a known Rap1p-binding site (Buchman et al. 1988). Although we cannot exclude a role for other rDNA-associated proteins, the distribution of Ty5 insertions suggests that the same proteins responsible for the assembly of the Sir complex at the telomeres and mating silent loci may also nucleate the assembly of the Sir complex at the rDNA. Chemical cross-linking of Sir2p to the rDNA has shown previously that it is preferentially localized in the vicinity of the $5 \mathrm{~S}$ gene, supporting a nonrandom distribution of silencing factors within the rDNA (Gotta et al. 1997). Defining chromatin at the rDNA is an active area of investigation, particularly because of its role in aging, and as described more recently, because of its role in the cell cycle (Shou et al. 1999; Straight et al. 1999). Monitoring Ty5-targeting patterns provides a new tool for dissecting rDNA chromatin dynamics.

Approximately $74 \%$ of the insertions in sir4-42 are not associated with the rDNA. Among these, we observed a high incidence of insertions (6/15) into or near pre-existing Ty1 or Ty3 elements. In $\Delta$ sir4 strains, $2 / 9$ insertions were also within or near Ty1 elements. It may be that when targeting to silent chromatin is disrupted, Ty5 defaults to a Tyl-like targeting mechanism recognizing RNA Pol III transcriptional machinery. We do not find this explanation particularly compelling, however, because insertions into Ty1 and Ty3 were not recovered in $\Delta$ sir2 or $\Delta$ sir3 strains, both of which have targeting defects. A second possibility is that the Ty-associated insertions in sir4-42 strains identify other sites at which silent chromatin assembles in genetically aged cells. Because of their dispersed nature, these loci are likely difficult to observe in immunofluorescence studies of Sir complex localization, and Ty5 therefore may be a more sensitive tool for monitoring chromatin changes. Aging is typically associated with a decrease in translational efficiency (Sinclair et al. 1998), and alterations in chromatin structure may be associated with genes other than the rDNA that encode components of the translational apparatus. Candidates include tRNA genes, which are
Ty1 and Ty3 integration hotspots and may explain the observed targeting pattern in sir4-42. Recently, it has been shown that a Ty1 LTR and tRNA gene can serve as boundary elements that delimit silent chromatin at the $H M R$ locus (Donze et al. 1999). Alternatively, Ty5 may sense changes in chromatin assembled at native Ty insertions. A more exhaustive survey of insertions in sir442 strains will be required to identify significant targeting trends and to further develop these alternative hypotheses. Nonetheless, the data presented here indicate that Ty5, and retrotransposons in general, may be powerful tools for dissecting the mechanisms underlying chromatin remodeling.

\section{Materials and methods}

\section{Strains}

The genotypes and sources of the yeast strains used in this study are listed in Table 7. YSZ269, which carries the sir4-42 allele, was constructed by integrating plasmid pSZ289 at the TRP1 locus of JRY4582 (gift of Jasper Rine, University of California, Berkeley). pSZ289 was constructed by first cloning a SacII/ClaI fragment of SIR4 from pRS316-SIR4 (gift of Jasper Rine, University of California, Berkeley) into pRS404 (Sikorski and Hieter 1989). This generated plasmid pSZ268. PCR was carried out with primers DVO408 and DVO409 to amplify the carboxyl terminus of SIR4. Primer DVO408 generates a stop codon at amino acid 1238, which is the mutation found in the sir4-42 allele (Kennedy et al. 1995). The amplification product was cloned, and the entire sequence was confirmed by DNA sequencing. The mutagenized carboxyl terminus was then used to replace the wild-type fragment of pSZ268, generating pSZ286. A transcriptional terminator from MRP2 (Peterson and Myers 1993) was inserted into the SalI/BgIII sites downstream of the sir4-42 carboxyl terminus to create pSZ289. One-step gene disruption was used to make all RAD52 deletions, with plasmids pSM20 (TRP1 marker) or pMS21 (LEU2 marker) (gift of L. Prakash and S. Prakash, University of Texas, Galveston). Gene disruptions were confirmed by PCR with primers DVO392 and DVO393, which are complementary to the RAD52 gene. HMR deletion strains were constructed by one-step PCR gene disruption with primers DVO1066 and DVO1069. HMR deletions were confirmed by PCR and mating tests.

\section{Integration and recombination assays}

All yeast strains carry the plasmid pNK254, which has a Ty5 element under transcriptional control of the GAL1-10 promoter and a his $3 A I$ selectable marker gene (Ke and Voytas 1997). Yeast cells were initially grown as patches on synthetic complete medium without uracil and with glucose (SC-U + glucose) at $30^{\circ} \mathrm{C}$ for 2 days. Patches were subsequently replica plated to complete media without uracil and with galactose (SC-U + galactose) to induce transposition and were grown at $23^{\circ} \mathrm{C}$ for an additional 2 days. To calculate transposition efficiency, cells were scraped from the plates and resuspended in $1 \mathrm{ml}$ of sterile water. For each patch, $100 \mu \mathrm{l}$ of a $10^{5}$-fold dilution was plated onto nonselective medium (YPD) to calculate the total cell number. A total of $100 \mu \mathrm{l}$ of the original suspension (or a 10-fold dilution) was plated onto selective medium without histidine (SC-H) to select cells with Ty5 cDNA integration or recombination events. The frequency of $\mathrm{His}^{+}$cell formation was calculated as the ratio of the number of colonies on SC-H plates to the num- 
Table 7. Yeast strains and oligonucleotides used in this study

\begin{tabular}{|c|c|c|}
\hline Strain & Genotype & Source \\
\hline $\begin{array}{l}\text { W303-1B } \\
\text { AMR26 } \\
\text { YDS71 } \\
\text { YDS73 } \\
\text { YAB61 } \\
\text { JRY4582 } \\
\text { YSZ269 } \\
\text { YYZ1 } \\
\text { YYZ3 } \\
\text { YYZ4 } \\
\text { YYZ5 } \\
\text { YYZ48 } \\
\text { YYZ212 } \\
\text { YYZ213 } \\
\text { YYZ214 } \\
\text { YYZ215 }\end{array}$ & $\begin{array}{l}\text { MAT } \alpha \text { ade2-1 can } 1-100 \text { his3-11,15 leu2-3 trp1-1 ura3-1 } \\
\text { W303-1B sir1::LEU2 } \\
\text { W303-1B sir2::TRP1 } \\
\text { W303-1B sir3::LEU2 } \\
\text { W303-1B HMR-E aeb } \\
\text { W303-1B ADE2 } \Delta \text { lys2 sir4::LEU2 } \\
\text { JRY4582 TRP1 sir4-42 } \\
\text { W303-1B rad52::TRP1 } \\
\text { YDS71 rad52::LEU2 } \\
\text { RS862 rad52::LEU2 } \\
\text { JRY4582 rad52::TRP1 } \\
\text { YSZ269 rad52::TRP1 } \\
\text { JRY4582 hmr::TRP1 } \\
\text { AMR26 hmr::TRP1 } \\
\text { YDS71 hmr::LEU2 } \\
\text { YDS73 hmr::TRP1 }\end{array}$ & $\begin{array}{l}\text { Alan Myers } \\
\text { Rolf Sternglanz } \\
\text { Rolf Sternglanz } \\
\text { Rolf Sternglanz } \\
\text { Rolf Sternglanz } \\
\text { Jasper Rine } \\
\text { this study } \\
\text { this study } \\
\text { this study } \\
\text { this study } \\
\text { this study } \\
\text { this study } \\
\text { this study } \\
\text { this study } \\
\text { this study } \\
\text { this study }\end{array}$ \\
\hline Oligo & Sequence & Gene \\
\hline $\begin{array}{l}\text { DVO208 } \\
\text { DVO308 } \\
\text { DVO309 } \\
\text { DVO392 } \\
\text { DVO393 } \\
\text { DVO495 } \\
\text { DVO496 } \\
\text { DVO583 } \\
\text { DVO247 } \\
\text { DVO212 } \\
\text { DVO251 } \\
\text { DVO252 } \\
\text { DVO211 } \\
\text { DVO253 } \\
\text { DVO1066 }\end{array}$ & $\begin{array}{l}\text { 5'-CAGCCGGAATGCTTGGCCA-3' } \\
\text { 5'-AGATCTCACCATGGAAAGGCTTCG-3' } \\
\text { 5'-ATCGATGAACGGCTCATTGGAATAA-3' } \\
\text { 5'-ATCTCCAAGAGAGTTGGG } \\
\text { 5'-GCCTCAGCAGGTGCGGCC } \\
\text { 5'-CCATAGTTTCTGTGTACAAGAGT-3' } \\
\text { 5'-CTTGTCTAAAACATTACTGAAACAAT-3' } \\
\text { 5'-GGACAAATAGTGTATTCAGCCGTC-3' } \\
\text { 5'-CACGAGCTCATCTAGAGCC-3' } \\
\text { 5'-ACCAGAGAGTGTAACAACAG-3' } \\
\text { 5'-TGCTGAAGTACGTGGTGAC-3' } \\
\text { 5'-TTCTCGAAGTAAGCATCAAC-3' } \\
\text { 5'-TGGTAGAAGCAGTAGTAACT-3' } \\
\text { 5'-AGCCCTATTCGCGTCGTG-3' } \\
\text { 5'-CCCGACTATGCTATTTTAATCATTGAAAACGAA } \\
\text { TTTATTTAGATTGTACTGAGAGTGCAC-3' }\end{array}$ & $\begin{array}{l}\text { HIS3 } \\
\text { SNF6 } \\
\text { SNF6 } \\
\text { RAD52 } \\
\text { RAD52 } \\
\text { Ty5 LTR } \\
\text { Ty5 LTR } \\
\text { Ty5 GAG } \\
H M L-E \\
H M R \text {-E and } H M L-\mathrm{E} \\
H M R \text {-I and } H M L-\mathrm{I} \\
H M L-\mathrm{I} \\
H M R-\mathrm{E} \\
H M R-\mathrm{I} \\
H M R\end{array}$ \\
\hline DVO1069 & $\begin{array}{l}\text { 5'-TATCGTCATATACAAATCTAGAAATTACCAGAG } \\
\text { CTATCCACTGTGCGGTATTTTCACACCG-3' }\end{array}$ & $H M R$ \\
\hline DVO1070 & 5'-TACGAAGATTCTCGATTCCG & $H M R$ \\
\hline DVO1079 & 5'-TTACTGTTGCGGAAAGCTGA & $H M R$ \\
\hline DVO553 & 5'-CACCCACTACACTACTCGGTCAGG-3' & rDNA \\
\hline DVO554 & 5'-ATCTGGTTGATCCTGCCAGTAGTC-3' & rDNA \\
\hline DVO555 & 5'-TCTGTTTGGTAGTGAGTGATACTC-3' & rDNA \\
\hline DVO556 & 5'-AGACCCTGTTGAGCTTGACTCTAG-3' & rDNA \\
\hline DVO575 & 5'-TTCCGCACСТTTTCСТCTGTCСAC-3' & rDNA \\
\hline DVO576 & 5'-AAGACCCGAATGGGCCCTGTATCG-3' & rDNA \\
\hline DVO577 & 5'-AGAGGGCACAAAACACCATGTCTG-3' & rDNA \\
\hline DVO578 & 5'-TATCCGAATGAACTGTTCCTCTCG-3' & rDNA \\
\hline DVO408 & 5'-GGACTAGTTAAGTACCAGTTTGTGAATGT-3' & $\operatorname{sir} 4-42$ \\
\hline DVO409 & 5'CCCAAGCTTACAGAACAAGCCTGATGCA-3' & SIR4 \\
\hline
\end{tabular}

ber of colonies on YPD plates adjusted by the dilution factor. To identify plasmid recombinants, $\mathrm{His}^{+}$colonies were streaked onto SC-H medium with 5-fluoroorotic acid (SC-H + 5-FOA). 5-FOA selects against the URA3 gene (Boeke et al. 1987), and plasmid recombinants fail to grow on $\mathrm{SC}-\mathrm{H}+5$-FOA medium because both the URA3 and HIS 3 markers are carried on the same plasmid. The frequency of $\mathrm{His}^{+}$cells with chromosomal Ty5 insertions was calculated as the ratio of the number of colonies on SC-H + 5-FOA to the number of colonies on YPD plates.

To distinguish between chromosomal recombination and integration events, yeast colony PCR was carried out with the
$\mathrm{His}^{+} / 5-\mathrm{FOA}^{\mathrm{r}}$ strains (Ausubel et al. 1987). Integration events were identified with a Ty5-specific primer (DVO496) and an HIS3-specific primer (DVO208). A specific 0.6-kb fragment was amplified from genomic DNA of cells with Ty5 integration events; no such band was amplified from DNA of $\mathrm{His}^{+} / 5-\mathrm{FOA}^{\mathrm{r}}$ cells that had undergone gene conversion of his3-11,15. Another pair of primers (DVO308 and DVO309), that amplify a 0.9-kb fragment of the SNF6 gene served as a PCR control. Amplifications were performed for 30 cycles by the following program: $94^{\circ} \mathrm{C}$ for $1 \mathrm{~min}, 48^{\circ} \mathrm{C}$ for $1 \mathrm{~min}$, and $72^{\circ} \mathrm{C}$ for $2 \mathrm{~min}$, with a final extension step of $72^{\circ} \mathrm{C}$ for $10 \mathrm{~min}$. Percent integration was calculated by dividing the number of the samples with both 
the 0.6-kb Ty5 fragment and the 0.9-kb SNF6 control fragment by the total samples with the $0.9-\mathrm{kb}$ SNF6 fragment. The overall transposition efficiency was calculated as the frequency of $\mathrm{His}^{+}$ cells with Ty5 on the chromosome times the percent integration.

\section{Mapping chromosomal Ty5 integration events}

To obtain strains with independent Ty5 integration events, $\mathrm{His}^{+}$ wild-type or $\Delta$ sir strains were generated by the above transposition protocol. Chromosomal integration events were identified by the PCR method described above and confirmed by Southern blot analysis (Ausubel et al. 1987). Filters were hybridized with radiolabeled Ty5 integrase, LTR and HIS3 probes. $\mathrm{His}^{+} / 5-\mathrm{FOA}^{\mathrm{r}}$ strains carrying one integrase band, two LTR bands, and two HIS3 bands were considered integration events. $\mathrm{His}^{+} / 5-\mathrm{FOA}^{\mathrm{r}}$ strains with no integrase band and no LTR bands and only one HIS 3 band were considered to have arisen by gene conversion of the endogenous his3-11,15 allele by the HIS 3 marker on the Ty5 cDNA. Sequences flanking the Ty5 integration sites were amplified as described previously by inverse PCR (Zou et al. 1996a), sequenced, and mapped onto the complete $S$. cerevisiae genome sequence (Cherry et al. 1997).

\section{A PCR Assay to monitor Ty5 integration near the HM loci}

Pools of genomic DNA were prepared from $10 \mathrm{His}^{+} / 5-\mathrm{FOA}^{\mathrm{r}}$ strains representing 10 independent chromosomal events (Ausubel et al. 1987). The majority of $\mathrm{His}^{+} / 5-\mathrm{FOA}^{\mathrm{r}}$ strains were assumed to have only one Ty5 element as supported by the previous characterization of $>70 \mathrm{His}^{+} / 5-\mathrm{FOA}^{\mathrm{r}}$ strains (Zou et al. 1996a,b; Zou and Voytas 1997). Integration events near the $H M$ loci were identified and confirmed by PCR screening with four groups of four primers. Each group included two Ty5 LTR-specific primers (DVO495 and DVO496) and two primers that amplified a $\sim 2-\mathrm{kb}$ window flanking one of the silencers (HML-E, DVO247 and DVO212; HML-I, DVO251 and DVO252; HMR-E, DVO211 and DVO212, or HMR-I, DVO251, and DVO253). Because DNA from most of the strains in each reaction did not have a Ty5 element near the tested silencer, the presence of the $\sim 2$-kb band served as a control for the PCR reaction. Amplifications were performed with $50 \mathrm{ng}$ of the pooled genomic DNA for 30 cycles by the following program: $94^{\circ} \mathrm{C}$ for $1 \mathrm{~min}, 48^{\circ} \mathrm{C}$ for $1 \mathrm{~min}$, and $72^{\circ} \mathrm{C}$ for $3 \mathrm{~min}$, with a final extension step at $72^{\circ} \mathrm{C}$ for $10 \mathrm{~min}$.

\section{A PCR assay to monitor Ty5 integration within the rDNA}

Genomic DNA was prepared from individual $\mathrm{His}^{+} / 5-\mathrm{FOA}^{\mathrm{r}}$ strains, each representing independent chromosomal integration events. Insertions within the rDNA were identified and confirmed by PCR screening. Each reaction included three Ty5specific primers (DVO495, DVO496, and DVO583) and four primers complementary to the same rDNA strand (Group 1: DVO553, DVO554, DVO555, DVO556; Group 2: DVO575, DVO576, DVO577, DVO578). The entire 9.1-kb rDNA repeat was covered by the eight rDNA primers so that any Ty5 insertion within the rDNA could be identified by two rounds of PCR. The amplification of a 1.6-kb Ty5 fragment by DVO583 and DVO495 served as a control for the PCR reactions and indicated the presence of Ty5 in the genome. Once an insertion was identified, additional rounds of PCR were conducted with individual Ty5 and rDNA primers to confirm its presence and to map it within the rDNA. Amplifications were performed with $50 \mathrm{ng}$ of DNA for 30 cycles by the following program: $94^{\circ} \mathrm{C}$ for $1 \mathrm{~min}$, $60^{\circ} \mathrm{C}$ for $1 \mathrm{~min}$, and $72^{\circ} \mathrm{C}$ for $2 \mathrm{~min}$, with a final extension step at $72^{\circ} \mathrm{C}$ for $10 \mathrm{~min}$.

\section{Acknowledgments}

We thank R. Sternglanz, J. Rine, and A. Myers for providing strains used in this study. This work was funded by American Cancer Society Grant VM145 to D.F.V. This is Journal Paper No. J-18446 of the Iowa Agriculture and Home Economics Experiment Station, Ames, IA, Project No. 3383, and was supported by Hatch Act and State of Iowa Funds.

The publication costs of this article were defrayed in part by payment of page charges. This article must therefore be hereby marked 'advertisement' in accordance with 18 USC section 1734 solely to indicate this fact.

\section{References}

Aparicio, O.M., B.L. Billington, and D.E. Gottschling. 1991. Modifiers of position effect are shared between telomeric and silent mating-type loci in S. cerevisiae. Cell 66: 12791287.

Ausubel, F.M., R. Brent, R.E. Kingston, D.D. Moore, J.G. Seidman, J.A. Smith, and K. Struhl. 1987. Current protocols in molecular biology. Greene/Wiley Interscience, New York, NY.

Astrom, S.U., S.M. Okamura, and J. Rine. 1999. Yeast cell-type regulation of DNA repair. Nature 397: 310.

Boeke, J.D. and S.B. Sandmeyer. 1991. Yeast transposable elements. In The molecular and cellular biology of the yeast Saccharomyces. (ed. J. Broach, E. Jones, and J. Pringle), Vol. 1, pp. 193-261. Cold Spring Harbor Laboratory Press, Cold Spring Harbor, NY.

Boeke, J.D. and S.E. Devine. 1998. Yeast retrotransposons: Finding a nice quiet neighborhood. Cell 93: 1087-1089.

Boeke, J.D., J. Trueheart, G. Natsoulis, and G.R. Fink. 1987. 5-Fluoroorotic acid as a selective agent in yeast molecular genetics. Methods Enzymol. 154: 164-175.

Brown, P.O. 1997. Integration. In Retroviruses. (ed. J. Coffin, S. Hughes, and H. Varmus), pp. 161-204. Cold Spring Harbor Laboratory Press, Cold Spring Harbor, NY.

Bryk, M., M. Banerjee, M. Murphy, K.E. Knudsen, D.J. Garfinkel, and M.J. Curcio. 1997. Transcriptional silencing of Ty1 elements in the RDN1 locus of yeast. Genes \& Dev. 11: $255-269$.

Buchman, A.R., N.F. Lue, and R.D. Kornberg. 1988. Connections between transcriptional activators, silencers, and telomeres as revealed by functional analysis of a yeast DNAbinding protein. Mol. Cell. Biol. 8: 5086-5099.

Bushman, F. 1995. Targeting retroviral integration. Science 267: $1443-1444$

Chalker, D.L. and S.B. Sandmeyer. 1992. Ty3 integrates within the region of RNA polymerase III transcription initiation. Genes \& Dev. 6: 117-128.

Cherry, J.M., C. Ball, S. Weng, G. Juvik, R. Schmidt, C. Adler, B. Dunn, S. Dwight, L. Riles, R.K. Mortimer et al. 1997. Genetic and physical maps of Saccharomyces cerevisiae. $\mathrm{Na}$ ture 387: 67-73.

Craigie, R. 1992. Hotspots and warm spots: Integration specificity of retroelements. Trends Genet. 8: 187-190.

Daniel, R., R.A. Katz, and A.M. Skalka. 1999. A role for DNAPK in retroviral DNA integration. Science 284: 644-647.

Devine, S.E. and J.D. Boeke. 1996. Integration of the yeast retrotransposon Tyl is targeted to regions upstream of genes 
transcribed by RNA polymerase III. Genes \& Dev. 10: 620 633.

Donze, D., C.R. Adams, J. Rine, and R.T. Kamakaka. 1999. The boundaries of the silenced HMR domain in Saccharomyces cerevisiae. Genes \& Dev. 13: 698-708.

Gai, X. and D.F. Voytas. 1998. A single amino acid change in the yeast retrotransposon Ty5 abolishes targeting to silent chromatin. Mol. Cell 1: 1051-1055.

Gotta, M., S. Strahl-Bolsinger, H. Renauld, T. Laroche, B.K. Kennedy, M. Grunstein, and S.M. Gasser. 1997. Localization of Sir2p: The nucleolus as a compartment for silent information regulators. EMBO J. 16: 3243-3255.

Kang, J.J., T.J. Yokoi, and M.J. Holland. 1995. Binding sites for abundant nuclear factors modulate RNA polymerase I-dependent enhancer function in Saccharomyces cerevisiae. I. Biol. Chem. 270: 28723-28732.

Ke, N. and D.F. Voytas. 1997. High frequency cDNA recombination of the Saccharomyces retrotransposon Ty5: The LTR mediates formation of tandem elements. Genetics 147: 545556.

- 1999. cDNA of the yeast retrotransposon Ty5 preferentially recombines with substrates in silent chromatin. Mol. Cell. Biol. 19: 484-494.

Kennedy, B.K., N.R. Austriaco, Jr., J. Zhang, and L. Guarente. 1995. Mutation in the silencing gene SIR4 can delay aging in S. cerevisiae. Cell 80: 485-496.

Kennedy, B.K., M. Gotta, D.A. Sinclair, K. Mills, D.S. McNabb, M. Murthy, S.M. Pak, T. Laroche, S.M. Gasser, and L. Guarente. 1997. Redistribution of silencing proteins from telomeres to the nucleolus is associated with extension of life span in S. cerevisiae. Cell 89: 381-391.

Kim, J.M., S. Vanguri, J.D. Boeke, A. Gabriel, and D.F. Voytas. 1998. Transposable elements and genome organization: A comprehensive survey of retrotransposons revealed by the complete Saccharomyces cerevisiae genome sequence. Genome Res. 8: 464-478.

Kirchner, J., C.M. Connolly, and S.B. Sandmeyer. 1995. Requirement of RNA polymerase III transcription factors for in vitro position-specific integration of a retroviruslike element. Science 267: 1488-1491.

Loo, S. and J. Rine. 1995. Silencing and heritable domains of gene expression. Annu. Rev. Cell. Dev. Biol. 11: 519-548.

Lustig, A.J. 1998. Mechanisms of silencing in Saccharomyces cerevisiae. Curr. Opin. Genet. Dev. 8: 233-239.

Martin, S.G., T. Laroche, N. Suka, M. Grunstein, and S.M. Gasser. 1999. Relocalization of telomeric Ku and SIR proteins in response to DNA strand breaks in yeast. Cell 97: 621-633.

Miller, C.A. and D. Kowalski. 1993. cis-acting components in the replication origin from ribosomal DNA of Saccharomyces cerevisiae. Mol. Cell. Biol. 13: 5360-5369.

Mills, K.D., D.A. Sinclair, and L. Guarente. 1999. MEC1-dependent redistribution of the Sir3 silencing protein from telomeres to DNA double-strand breaks. Cell 97: 609-620.

Peterson, J.A. and A.M. Myers. 1993. Functional analysis of mRNA 3' end formation signals in the convergent and overlapping transcription units of the $S$. cerevisiae genes RHO1 and MRP2. Nucleic Acids Res. 21: 5500-5508.

Petes, T.D., R.E. Malone, and L.S. Symington. 1991. Recombination in yeast. In The molecular and cellular biology of the yeast Saccharomyces. (ed. J. Broach, E. Jones, and J. Pringle), Vol. 1. pp. 407-421. Cold Spring Harbor Laboratory Press, Cold Spring Harbor, NY.

Pillus, L. and J. Rine. 1989. Epigenetic inheritance of transcriptional states in S. cerevisiae. Cell 59: 637-647.

Sandmeyer, S.B., L.J. Hansen, and D.L. Chalker. 1990. Integration specificity of retrotransposons and retroviruses. Annu.
Rev. Genet. 24: 491-518.

Sharon, G., T.J. Burkett, and D.J. Garfinkel. 1994. Efficient homologous recombination of Tyl element cDNA when integration is blocked. Mol. Cell. Biol. 14: 6540-6551.

Shou, W., J.H. Seol, A. Shevchenko, C. Baskerville, D. Moazed, Z.W. Chen, J. Jang, H. Charbonneau, and R.J. Deshaies. 1999. Exit from mitosis is triggered by Tem1-dependent release of the protein phosphatase Cdc14 from nucleolar RENT complex. Cell 97: 233-244.

Sikorski, R.S. and P. Hieter. 1989. A system of shuttle vectors and yeast host strains designed for efficient manipulation of DNA in Saccharomyces cerevisiae. Genetics 122: 19-27.

Sinclair, D., K. Mills, and L. Guarente. 1998. Aging in Saccharomyces cerevisiae. Annu. Rev. Microbiol. 52: 533-560.

Smith, J.S. and J.D. Boeke. 1997. An unusual form of transcriptional silencing in yeast ribosomal DNA. Genes \& Dev. 11: $241-254$.

Straight, A.F., W. Shou, G.J. Dowd, C.W. Turck, R.J. Deshaies, A.D. Johnson, and D. Moazed. 1999. Net1, a Sir2-associated nucleolar protein required for rDNA silencing and nucleolar integrity. Cell 97: 245-256.

Tsukamoto, Y., J. Kato, and H. Ikeda. 1998. Silencing factors participate in DNA repair and recombination in Saccharomyces cerevisiae. Nature 388: 900-903.

Voytas, D.F. and J.D. Boeke. 1992. Yeast retrotransposon revealed. Nature 358: 717

Zou, S. and D.F. Voytas. 1997. Silent chromatin determines target preference of the Saccharomyces retrotransposon Ty5. Proc. Natl. Acad. Sci. 94: 7412-7416.

Zou, S., N. Ke, J.M. Kim, and D.F. Voytas. 1996a. The Saccharomyces retrotransposon Ty5 integrates preferentially into regions of silent chromatin at the telomeres and mating loci. Genes \& Dev. 10: 634-645.

Zou, S., J.M. Kim, and D.F. Voytas. 1996b. The Saccharomyces retrotransposon Ty5 influences the organization of chromosome ends. Nucleic Acids Res. 24: 4825-4831. 


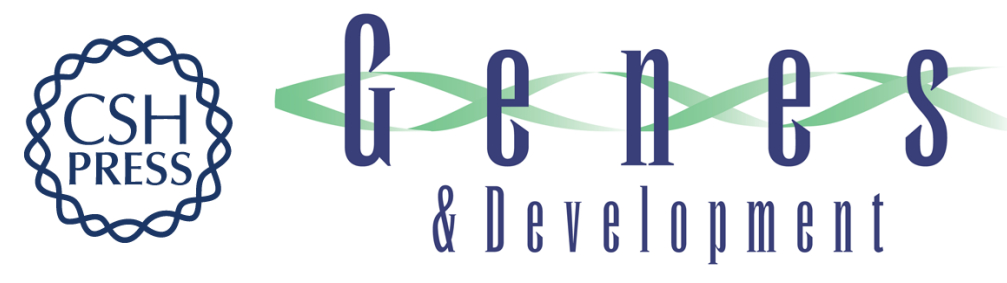

\section{Tagging chromatin with retrotransposons: target specificity of the Saccharomyces Ty5 retrotransposon changes with the chromosomal localization of Sir3p and Sir4p}

Yunxia Zhu, Sige Zou, David A. Wright, et al.

Genes Dev. 1999, 13:

References This article cites 40 articles, 19 of which can be accessed free at:

http://genesdev.cshlp.org/content/13/20/2738.full.html\#ref-list-1

License

Email Alerting Receive free email alerts when new articles cite this article - sign up in the box at the top Service right corner of the article or click here.

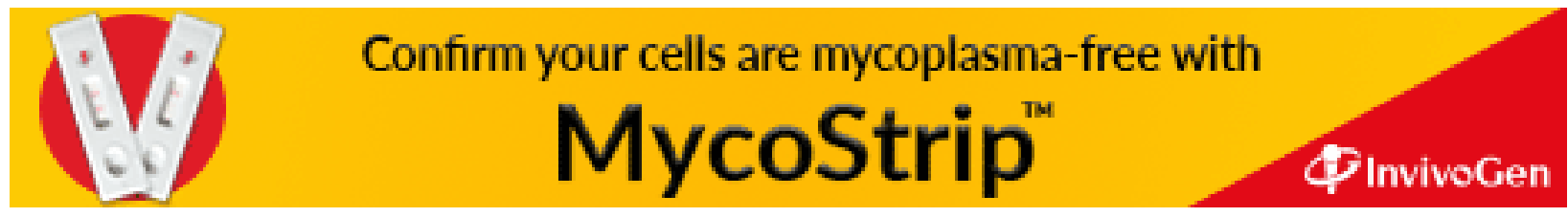

